\title{
A seismic swarm near Neshkan, Chukotka, northeastern Russia, and implications for the boundary of the Bering plate
}

\author{
K. G. Mackey ${ }^{1}$, K. Fujita ${ }^{1}$, B. M. Sedov ${ }^{2}$, L. V. Gounbina ${ }^{3}$, and S. Kurtkin ${ }^{3}$ \\ ${ }^{1}$ Department of Geological Sciences, Michigan State University, East Lansing, MI 48824, USA \\ ${ }^{2}$ Northeast Interdisciplinary Scientific Research Institute, Portovaya 16, Magadan 685000, Russia \\ ${ }^{3}$ Magadan Affiliate, Geophysical Survey of Russia, Russian Academy of Sciences, Skuridina 6b, Magadan 685024, Russia
}

\begin{abstract}
A seismic swarm lasting over two years occurred near the village of Neshkan, Chukotka, far northeastern Russia, beginning with a $M_{L}, 4.2\left(4.1 m_{b}\right)$ earthquake on 9 December 2002. The swarm generated considerable anxiety among the local populace and authorities. Two temporary seismic stations were deployed during the latter part of September 2003, and recorded over 150 events with magnitudes up to 3.0. Eighteen locatable events appear to form a northeast striking linear trend, parallel to other seismicity trends in Chukotka, extending $20 \mathrm{~km}$ to the southwest from the village. We interpret this trend as a previously unknown fault. A small pond located $\sim 1 \mathrm{~km}$ west of the village drained and some apparent surface deformation was observed over the course of the earthquake sequence. Relocation of historic seismicity in the region shows that a magnitude 6.0 in 1996 may have ruptured an adjacent fault segment. Other, less well located but larger, teleseismic events earlier in the 20th century may also have occurred on or near this fault. The seismicity is consistent a proposed region of transtension along the northern boundary of a Bering plate.
\end{abstract}

\section{Introduction}

The village of Neshkan is located along the Arctic Ocean on the northern coast of the Chukchi Peninsula, Chukotka, far northeastern Russia (Fig. 1). Earthquakes have been felt in Neshkan over the past 40 years, including moderate events such as the magnitude 6.0 event of 24 October 1996. Following a smaller, $M_{L} 4.2\left(4.1 m_{b}\right)$, event on 9 December 2002, however, residents began to experience earthquakes on an almost daily basis that continued for many months. There was considerable fear among the residents concerning the appar-

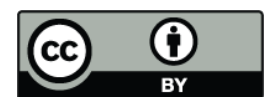

Correspondence to: K. G. Mackey (mackeyke@msu.edu) ently indefinite continuation of the events, and the fear of larger events in the future capable of destroying the village. The numerous reports of felt earthquakes received by the regional emergency office (MChS) in Anadyr, combined with lack of scientific knowledge about the events, raised concerns that the village may need to be abandoned or relocated to a safer area.

Neshkan lies near the northwest edge of a zone of seismicity that spans easternmost Chukotka, Alaska's Seward Peninsula, and extending into Alaska proper. This seismicity is suggested to represent a zone of transtension along the northern edge of a Bering plate that is rotating clockwise relative to North America (Fig. 1; Mackey et al., 1997; Fujita et al., 2002; Cross and Freymueller, 2008). Relative to stable North America, recent Global Positioning System (GPS) data indicate that the pole of rotation is located in southeastern Russia (Cross and Freymueller, 2008). Earthquake mechanisms, including the recent 2006 Olyutorka sequence discussed below, indicate that the pole of rotation of the Bering Plate relative to the adjacent, potentially less-rigid, portions of the North America plate in Asia is located in northwestern Chukotka (Mackey et al., 1997).

In 2002, the only seismic station operating in all of Chukotka was Bilibino, about $750 \mathrm{~km}$ distant (Fig. 1 inset). Earlier seismic monitoring between 1982 and 1993 was not useful in understanding the seismotectonics of the Neshkan region. During that time, the closest seismic station was Iul'tin, approximately $200 \mathrm{~km}$ away (Fig. 1). Although some small events were located in the general vicinity, the quality of epicenters was not sufficient to resolve any trends, and no large events occurred during this earlier time period.

We deployed a small seismic network near Neshkan in an effort to better understand the seismicity and seismic hazards in Neshkan and vicinity, the northern boundary of the Bering Plate as a whole, and to improve the ability to locate events in the region. This deployment was a joint effort conducted by the Magadan Experimental Methodological Seismological

Published by Copernicus Publications on behalf of the European Geosciences Union. 


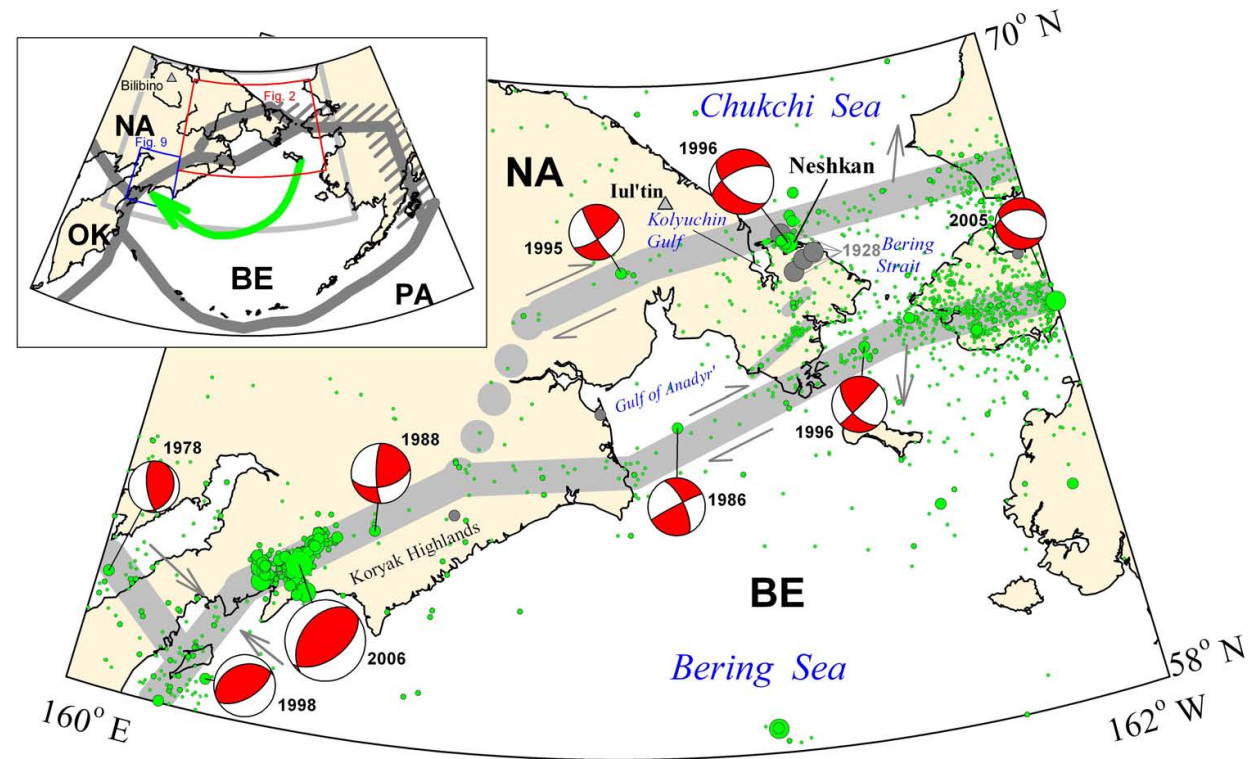

Fig. 1. Index map of the Chukotka region with seismicity and representative focal mechanisms of Chukotka and western Alaska (compressional quadrants shaded). Years are denoted for each mechanism. For seismicity, larger magnitudes depicted with larger circles. Solid grey epicenters indicate historic events prior to 1960. Arrows show relative motions between the plates. Inset shows regional map of the Bering plate; the arrow shows the motion of the Bering plate in a North America fixed reference frame. The red box shows the area of Fig. 2 and the blue box shows the area of Fig. 9. NA - North American plate, BE - Bering plate; hachured area denotes poorly known or diffuse boundary zone. Area of main map also shown by grey square on inset.

Division (Magadan EMSD, now Magadan Affiliate, Geophysical Survey, Russian Academy of Sciences), Michigan State University (MSU), and the Anadyr MChS office.

\section{Geologic setting}

The Bering Strait/Neshkan region has been proposed to be a region undergoing extension and rifting associated with movement of the Bering Block or microplate (Mackey et al., 1997). Motion of the Bering Block is estimated primarily through seismicity, focal mechanisms (Figs. 1 and 2; Lander et al., 1996; Mackey et al., 1997; Fujita et al., 2002), and GPS observations (Cross and Freymueller, 2008), and is suggested to be driven by terrane accretion in southern Alaska (Mackey et al., 1997).

Several lines of evidence have indicated the presence of an extensional regime in and around eastern Chukotka and the Seward Peninsula of Alaska since the Late Cretaceous. Young ( $<6 \mathrm{Ma}$ ) basalt fields are found on the Seward Peninsula and in west-central Alaska, and are associated with Quaternary normal faulting and hot springs (Hudson and Plafker, 1978; Turner and Forbes, 1980; Moll-Stalcup, 1994; Till and Dumoulin, 1994; Dumitru et al., 1995). In Chukotka, alkali basalts of Mid- to Late-Cenozoic age (Enmelen volcanics and others near Kolyuchin Gulf), similar to those in Seward Peninsula and western Alaska, are reported (Akinin and Apt, 1994; Belyi, 1970). Additional Quaternary basalts are also reported from eastern Chukotka (Anikeev et al., 1970). As in Seward Peninsula, numerous (approximately 30-40) hot springs exist in eastern Chukotka, including those near Provideniya, Novo Chaplino, Lavrentiya, and Uelen (Chesko et al., 2004; Polyak et al., 2005). Focal mechanism studies indicate north-south oriented extension on the Seward Peninsula, in the Bering Strait (Biswas et al., 1986), and in Chukotka (Fujita et al., 2002, and discussed in detail below). These suggest that a widespread extensional regime prevails in Chukotka and the Bering Strait region today.

Numerous faults (Fig. 3) have been mapped on the continental part of eastern Chukotka, south of Neshkan. Two sets of faults, northwest and northeast striking, cut through the area (e.g., Natal'in, 1999); in the past, the northeastsouthwest trending faults have generally been considered less significant by Russian geologists (e.g., Anikeev et al., 1970). Most regional faults have been defined primarily on the basis of potential fields and limited geomorphological data.

Field mapping in the Chegitun River valley, southeast of Neshkan (Toro et al., 2003), indicates that north-northeast striking faults may play a significant role in the tectonics of the area. Two right-lateral faults (Fig. 3) juxtapose platformal Paleozoic units with high-grade metamorphic rocks. These faults post-date metamorphism and ductile deformation that took place in the Late Cretaceous and Earliest Paleogene (Toro et al., 2003). These faults have been suggested to extend out into the Chukchi Sea and on towards Alaska (Natal'in, 1999). Additional faults of northwest strike 


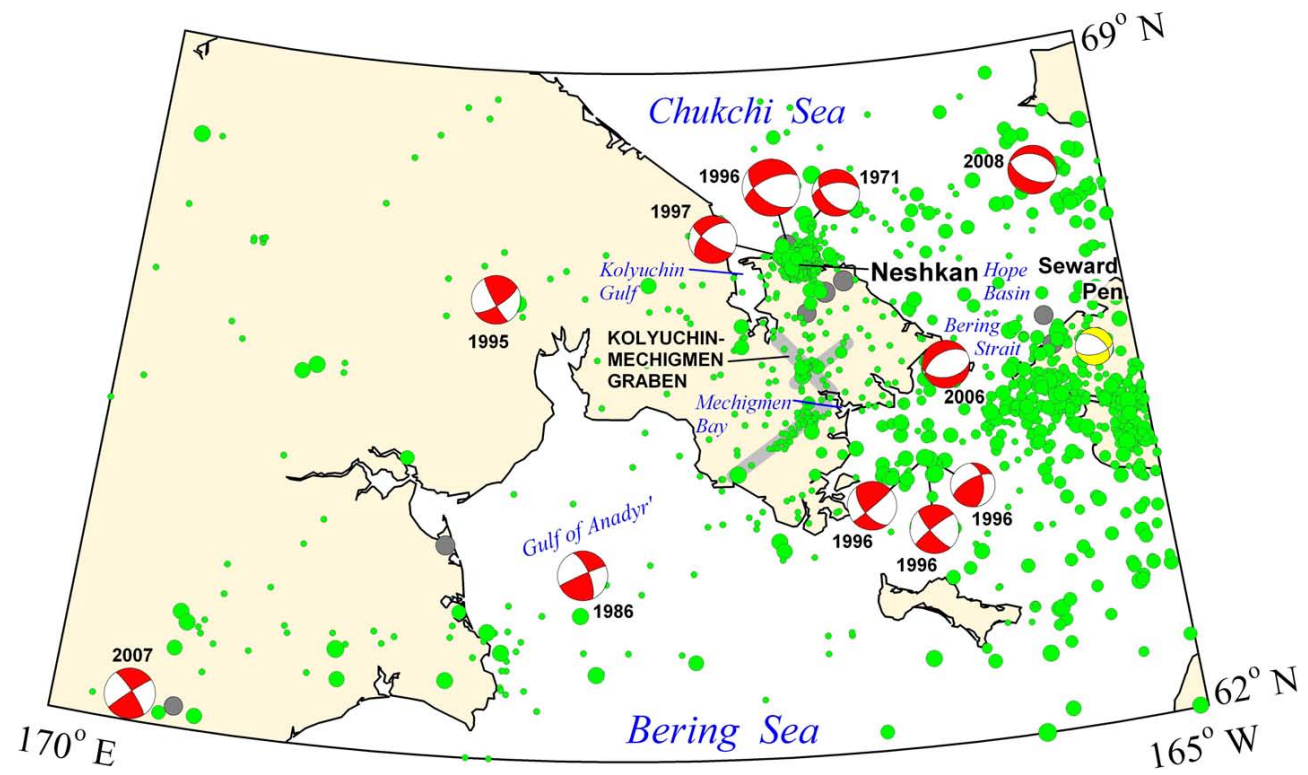

Fig. 2. Index and seismicity map of eastern Chukotka and the Neshkan region; historical events are shown in grey. Focal mechanisms for the region are shown. Red - moment tensors and reliable P-wave first motion mechanisms, and Yellow - P-wave composite mechanism (from Biswas et al., 1986). Compressional quadrants are shaded. Linear seismicity trends are shown in grey.

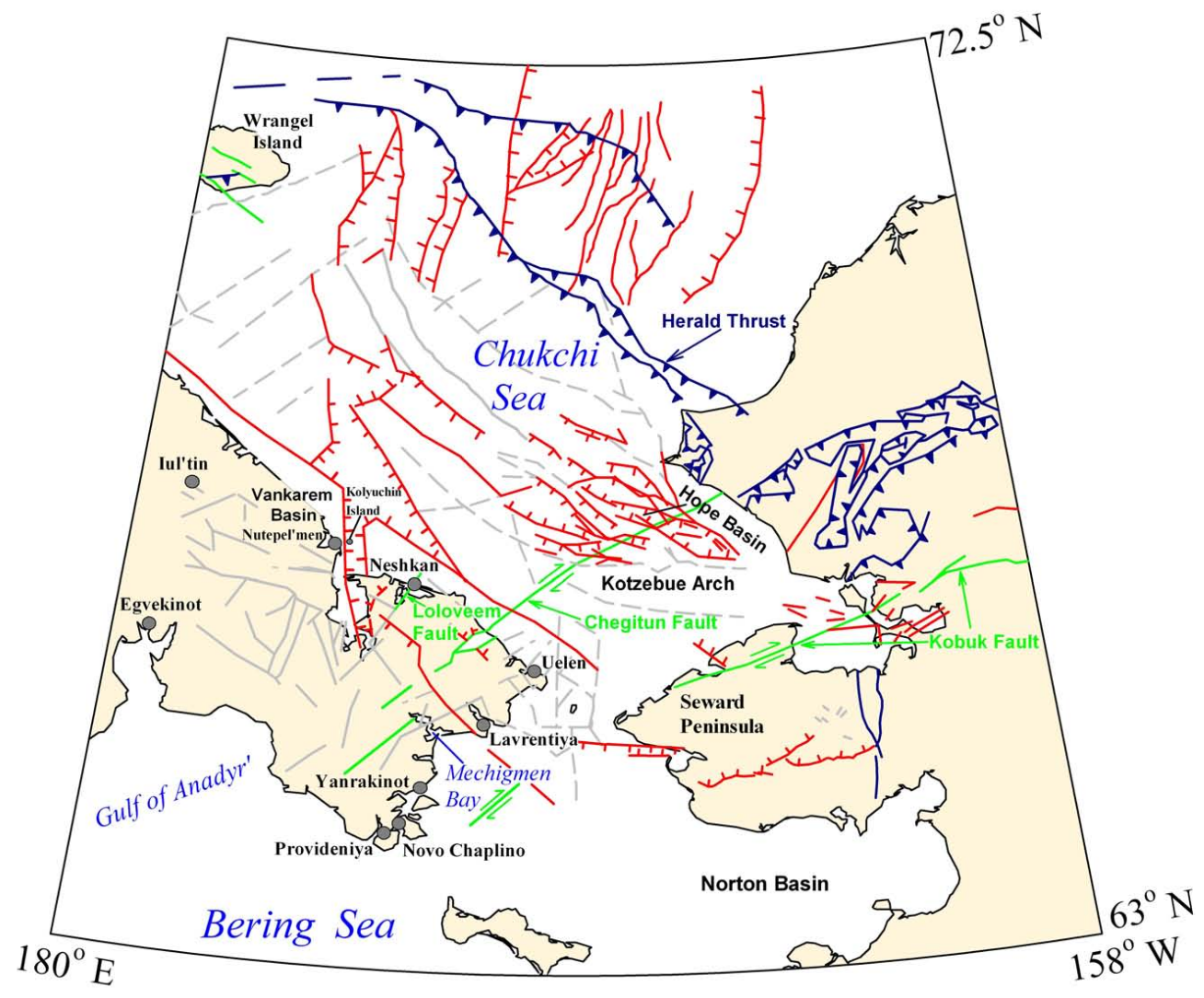

Fig. 3. Fault map of the Chukchi Sea and adjacent land areas. Compiled primarily from Natal'in (1999), Shipilov et al. (1989), Aksenov et al. (1987), Till and Dumoulin (1994), Gorodinsky (1982), and Grantz et al. (1994), with additions. Some fault locations and types based on Russian geophysical data may be highly interpretive. Normal faults shown in red (ticks on downthrown side), thrusts (teeth on upper plate) in blue, strike-slip (with direction of movement) in green. Grey denote faults of unknown character; dashed where approximate or speculative. 
cut units in the area. Toro et al. (2003) concluded that, in general, northeast striking faults are right-lateral strike-slip, while the northwest striking faults are normal, consistent with approximately north-south directed tension. No direct evidence of recently active extensional faulting has yet been reported from the continental part of Chukotka.

Russian geophysical investigations using both seismic reflection and potential fields have identified additional faults off the north coast of Chukotka and in the Bering Strait region (Aksenov et al., 1987; Shipilov et al., 1989). Unlike Toro et al. (2003), these authors suggest that faults of both northwest and northeast strike, i.e., parallel to the northern Bering Strait coasts of the Chukchi and Seward Peninsulas, are normal faults. Aksenov et al. (1987) suggest that the northwest striking faults appear to truncate other faults and thus may be younger, although no seismicity trends are associated with them.

Quaternary deposits dominate the study area and are composed of lagoonal mud, sand, loam, and pebbles and reach a maximum thickness in the basins of $\sim 100 \mathrm{~m}$ (Gorodinsky, 1982); occasionally, remnants of glacial moraines are found. Glacial outwash deposits, 1-4 m thick, consisting of sand, pebbles, gravel, and boulders, are more common along the coastline. The settlement of Neshkan is located along a barrier island along the coast of the Chukchi Sea (Fig. 4). Recent sediments consist of marine deltaic, alluvial, and bog deposits.

Seismic reflection and drilling-based stratigraphic studies in offshore Hope Basin indicate the presence of generally east-west striking basins with Eocene and younger fill bounded by normal faults which may have originated as early as the Paleogene (Fig. 3; Tolson, 1987). A similar age range of sediments are found in Norton Basin (Grantz et al., 2002) and uplift and regional tilting occurred contemporaneously in Seward Peninsula (Dumitru et al., 1995). Dumitru et al. (1995) also present evidence for an even earlier regional extensional episode in the mid-Cretaceous $(\sim 120$ to $\sim 70 \mathrm{Ma}$ ) based on uplift, formation of north-south stretching lineations, deformation, and pluton emplacement; similar features and ages are observed in the Koolen dome of Chukotka (Bering Strait Field Party, 1997; Natal'in et al., 1999).

Russian marine seismic surveys suggest the existence of a fault-bounded trough just offshore of Kolyuchin Gulf (Aksenov et al., 1987), which may be a reactivated portion of a much larger Cenozoic rift system that covered the western Chukchi Sea (Fig. 3; Shipilov et al., 1989). Seismic reflection profiles indicate that bounding faults cut Quaternary sediments in both areas (Eittreim et al., 1979; Shipilov, 1989) and vertical offsets of $40 \mathrm{~m}$ are recorded west of Cape Neshkan. The active rift system may terminate roughly at the meridian of Kolyuchin Gulf as indicated by the general lack of seismicity. There is also no indication in the Russian literature that these grabens extend to the west of Kolyuchin Gulf.

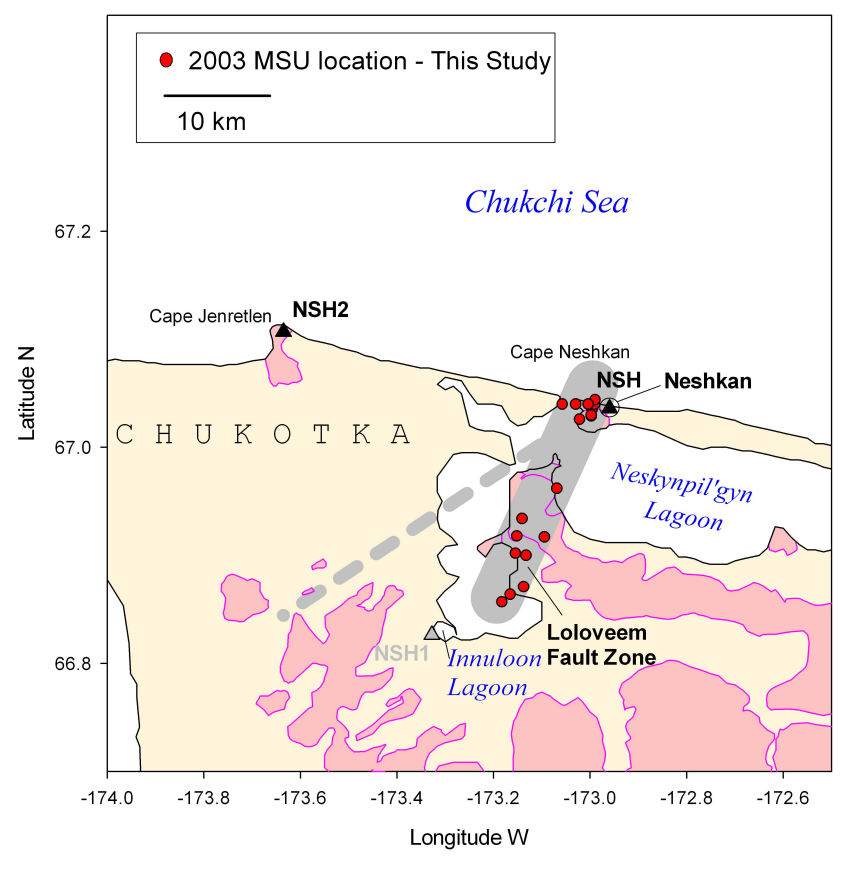

Fig. 4. Seismic station deployments and located events from the 2003 Neshkan experiment. Epicenters (red dots) calculated using two stations (black triangles) showing a generally linear trend of epicenters (grey band), here interpreted to be a distinct fault. Dashed grey band represents possible alternate distribution of epicenters (see text). Pre-Quaternary outcrop shown in pink. Grey triangle shows location of seismic station that failed to operate.

A topographic lowland, filled with Quaternary sediments (e.g., Gorodinsky, 1982) extends from the southern end of Kolyuchin Gulf to Mechigmen Bay on the Bering Strait (Fig. 2). Based primarily on geophysical data, this lowland been interpreted to represent a fault-bounded graben (Kolyuchin-Mechigmen graben), which initiated in Paleogene time (Pol'kin, 1984) with subsidence continuing up to the present (Kolyuchin neotectonic basin). The subsidence in eastern Chukotka is inferred to continue into the Quaternary (Aksenov et al., 1987). The lowland is spatially associated with, and may inherit structures from, the similarly named Mesozoic Kolyuchin-Mechigmen zone (also termed the Kolyuchin-Mechigmen rift), with which it should not be confused.

The Kolyuchin neotectonic basin, located to the southwest and west of Neshkan, underlies Kolyuchin Gulf (Fig. 2), parts of the adjacent land area, and some of the lowlands between Kolyuchin Gulf and Mechigmen Bay; it may also be contiguous with the Vankarem basin to the northwest. Based on boreholes drilled along the coast of Kolyuchin Gulf, near the presumed edges of the basin, it is filled with continental and, primarily, marine Cenozoic sediments with a thickness of 60-140 m (Gorodinsky, 1982). In the Vankarem basin, the Cenozoic reaches $215 \mathrm{~m}$ (Grinenko et al., 1998), and the sedimentary thickness may be greater offshore, in the Chukchi 
Sea, and within Kolyuchin Gulf itself. The eastern edge of the Kolyuchin basin has been proposed to extend with northnortheast strike along the western coast of Neskynpil'gyn Lagoon; in this interpretation, a small basement exposure $20 \mathrm{~km}$ west of Neshkan (Cape Jenretlen) can be considered as the westernmost exposure of the Cretaceous basement (Fig. 4).

\section{Neshkan swarm 2002-2004}

The swarm of earthquakes near Neshkan began with a $M_{L}$ 4.2 on 9 December 2002. Other magnitude estimates for this event range from 3.9-4.7, depending on magnitude type and source. Through October 2003, the ISC reported six additional events with magnitudes between 3 and 4, which may have been aftershocks occurring in this sequence. The ISC locations for these events vary considerably, thus it was not initially clear which of them were actually associated with mainshock versus other isolated events. Of the six possible aftershocks, 5 were reported as felt in Neshkan.

More significant were the daily (and multiple times per day) events felt in Neshkan. The first events, which could be considered foreshocks, apparently were felt around 2 December 2002. Minor events continued over the next few days until 9 December, when several events of MM (Modified Mercalli Intensity) II and greater were recorded, the largest of which, at 03:35 UTC (15:35 local time) was the teleseismically recorded $M_{L} 4.2$ "mainshock" and was felt with MM IV. Subsequently, earthquakes with intensities up to MM IV were felt multiple times per day. On 24 December, a $m_{b} 3.3$ event was felt at MM VI, and other MM IV-V events occurred over the following few weeks. A record of felt events was maintained by the local administrator, but is necessarily incomplete as so many events were being felt. The near daily events (a total of nearly 200 individual events were noted, although some days are indicated as "continuous events all day" without a count) continued through the spring and summer of 2003 and sporadically through all of 2004. Earthquakes continue to be felt in Neshkan through the present time (December 2008).

Due to the general disquiet of the people of Neshkan over these events, the local government and the regional emergency management service requested assistance from the Magadan EMSD to study these earthquakes. As a result, three seismic stations were initially deployed in and near Neshkan in the fall of 2003 by Magadan EMSD with assistance from Michigan State University (Fig. 4). The main station, NSH, was a three component short period station deployed in the city administration cabin of the village of Neshkan. Two temporary stations were deployed in the tundra. Station NSH1 was deployed in a small sand excavation on a hill just southwest of Innuloon Lagoon, and station NSH2 was deployed on a metamorphic rock outcrop on Cape Jenretlen. Both temporary stations were single-component using a short period vertical seismometer. Data were logged
Table 1. Seismic station parameters.

\begin{tabular}{lllll}
\hline Station & Latitude & Longitude & $\begin{array}{l}\text { Elevation } \\
(\mathrm{m})\end{array}$ & $\begin{array}{l}\text { Date } \\
\text { Open-Close }\end{array}$ \\
\hline NSH & 67.036 & -172.960 & 5 & 12 Sep 2003-Sep 2004 \\
NSH1 & 66.263 & -173.328 & 20 & Did not operate \\
NSH2 & 67.107 & -173.635 & 65 & 12-30 Sep 2003 \\
\hline
\end{tabular}

on notebook computers powered using several large batteries. All stations used 24 bit A/D cards and GPS clocks. Coordinates of the stations are given in Table 1. Unfortunately, station NSH1 failed shortly after installation due to an instrument problem and recorded no useful data.

Over approximately 18 days of operation, the Neshkan temporary deployment recorded approximately 150 earthquakes, most at station NSH. The largest event recorded during the experiment had a $M_{L}$ of approximately 3.4. Most events recorded were considerably smaller. 18 events were well recorded at both the NSH and NSH2 stations, allowing approximate locations to be calculated.

Epicenters were determined using a standard least squares inversion routine for 18 events with clear $\mathrm{Pg}$ and $\mathrm{Sg}$ arrivals recorded at both operating stations. For these events, first motions at the three component station Neshkan (NSH) were first determined. In most cases, first motions for all components were either up, north, and east, or down, south, and west, (Fig. 5) which in both cases restricts the epicenter to the southwest of NSH.

The closest locatable events had an S-P time of only $0.6 \mathrm{~s}$, restricting the maximum possible depth for many events near Neshkan to $5-7 \mathrm{~km}$, assuming the event is directly below the station. All events were thus located assuming the focal depth to be $5 \mathrm{~km}$ and using Pg and $\mathrm{Sg}$ arrival times from both stations.

The event locations fall in a linear zone extending from Neshkan to approximately $20 \mathrm{~km}$ to the south-southwest (Fig. 4). We suggest that this linear trend of earthquakes represents a previously unknown active fault which we will refer to as the Loloveem fault (Fig. 4), after a nearby river. The epicenters indicate that this fault passes within $1 \mathrm{~km}$ west of Neshkan. It should be noted that there is a trade-off between distance from Neshkan and focal depth; however, the general trend can be duplicated using various location methods, including analysis of particle motions.

In Fig. 4, we compare the location of the Loloveem fault to the edge of the Quaternary deposits southwest of Neshkan; the calculated band of epicenters has a south-southwest strike and cuts into areas where Precambrian formations are exposed. However, if the events farther from Neshkan are deeper than the assumed $5 \mathrm{~km}$, and/or the seismic velocity model used in the location procedure was too fast, the strike 


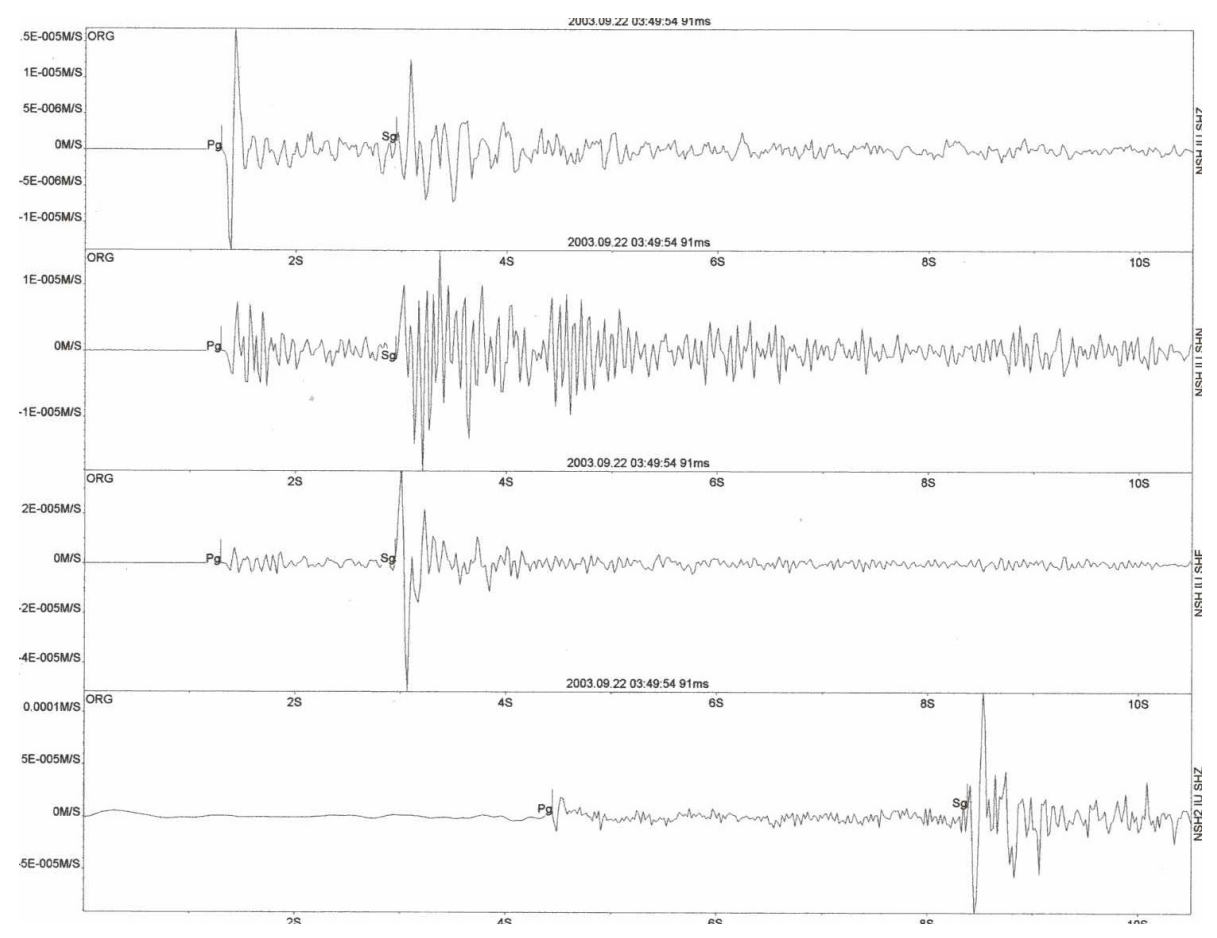

Fig. 5. Earthquake record with a dilatational arrival at station NSH. The top three traces are, top to bottom, vertical, N-S, and E-W components of station NSH. The bottom trace is the vertical from station NSH2.

of the epicenters, and thus the fault, would be more southwesterly (dashed grey line in Fig. 4). This strike is approximately parallel to the edge of Precambrian exposures southwest of Neshkan (excluding Cape Jenretlen) and, in this interpretation, the Loloveem fault may represent the eastern bounding fault of the Kolyuchin neotectonic basin.

Supporting the existence of the Loloveem fault that extends to shallow depth is the observation that a small pond located approximately $1 \mathrm{~km}$ west of the village drained for the first time in peoples' memory by spring, 2003. As the pond was completely frozen at the time, it would not have been possible for it to drain immediately following the mainshock event of 9 December 2002. An extensive region of rapidly eroding permafrost sand deposits developed approximately $500 \mathrm{~m}$ west of the village. This erosion was facilitated by extensive cracks in the permafrost, allowing water to penetrate and melt the permafrost in the warmer summer months, causing the crack to expand as material was washed out. It is the recollection of the village administrator that the cracks may have first appeared in 1997. This would be consistent with a small amount of surface deformation resulting from the $M_{w} 6.1$ Neshkan earthquake in October 1996. No other similar fractured erosional areas were observed in approximately $15 \mathrm{~km}$ of walking along the beach to the west of Neshkan or from limited helicopter observations in the region.
Following the end of active fieldwork in the Neshkan region, station NSH was left in place as a permanent station site. Analysis of data from 12 September 2003 through 30 August 2004 show that 2271 earthquakes were recorded sufficiently well that both P and S arrivals are clear (Fig. 6). Some events have S-P times as low as $0.1 \mathrm{~s}$, indicating a hypocenter of only a kilometer from the village. S-P times for most events are less than $1.3 \mathrm{~s}$. Very few events occur at distances corresponding to S-P times of 1.3-1.7 s, but the numbers then increase up to distances corresponding to S-P of $3.1 \mathrm{~s}$. There are no events with S-P greater than $3.1 \mathrm{~s}$. On average, the farther events are larger than the close events, as small farther events are not recorded due to attenuation. Attenuation alone cannot account for the sudden decrease in event numbers at S-P times of 1.3-1.7 s, but likely does affect the overall numbers at greater distances. By September 2004, data quality from the NSH had degraded due to leveling problems with the seismometers caused by shifting permafrost.

\section{Historical seismicity}

The Neshkan region has been very active seismically over the past century and is part of an active zone of earthquakes that extends across Chukotka from Kolyuchin Gulf in the northwest to the Provideniya area in the southeast (Figs. 1 and 2). The seismicity continues into Seward Peninsula to the 
east and the Koryak highlands to the west as part of a broad zone of diffuse seismicity that has been proposed to form the northern edge of the Bering plate (Mackey et al., 1997; Fujita et al., 2002; Figs. 1 and 2).

The seismicity recorded in our deployment near Neshkan appears to follow the proposed eastern boundary of the Kolyuchin basin with a north-northeast strike and its extrapolation would connect with the western end of the KolyuchinMechigmen graben. However, the seismicity does not fall along any previously recognized or geologically mapped fault.

The largest earthquakes to strike the Neshkan region occurred near Kolyuchin Gulf in 1928 (Fig. 1) with four events having magnitudes of 6.2-6.9. Given the poor location accuracy at the time, these events could be mislocated from a northeast striking trend about $50 \mathrm{~km}$ to the north defined by more recent seismicity and extending from Kolyuchin Gulf out into the Chukchi Sea, passing slightly to the west of Neshkan (Fujita et al., 2002). The more recent trend is also parallel to the edge of the topographic highlands formed by exposures of crystalline rocks east of Kolyuchin Gulf and with the trend identified by our 2003 deployment. Based on their size, the 1928 Kolyuchin Gulf events were undoubtedly felt throughout northern Chukotka; however, as there were no Russian settlements or scientific stations in the region, no felt reports exist. Both the 1928 and more recent seismicity are within location error of having occurred along the proposed Loloveem fault (see below).

Events of magnitude 5-6 occurred in this region in 1962, 1971, and 1996 (Fujita et al., 2002). Due to the lack of seismic stations in the region, locations calculated for events in eastern Chukotka can have location errors of tens of (perhaps up to a hundred) kilometers, especially for smaller events with magnitude less than 4 .

There are no felt reports for the 1962 event, which should have been felt a bit stronger than the 5 October 1971 event; the lack of reports is surprising as several scientific stations were operating in the area and Neshkan was an established settlement. The 1971 event was widely felt throughout Chukotka. Intensity V was reported from Neshkan, where people fled from homes and furniture and walls creaked. A rumbling sound was heard. Intensity IV was reported from Nutepel'men, Kolyuchin Island, Uelen, and Iul'tin (Fig. 3); dominantly light rocking (Lazareva, 1975). Its epicenter is calculated as being due north, and offshore, of Neshkan. The 1996 event was lightly felt (intensity IV-V) at Lavrentiya and Yanrakinot and weakly at Egvekinot and Provideniya (intensity III). The event was probably felt at settlements along the Chukchi Sea coast as well.

For the 9 December $2002 M_{L} 4.2$ mainshock, the teleseismically (ISC) determined epicenter appears to be mislocated approximately $10 \mathrm{~km}$ to the southwest relative to our newly defined Loloveem fault. Relocation of the mainshock, using data from the ISC bulletin supplemented by data from four stations operated by the Alaska Earthquake Information

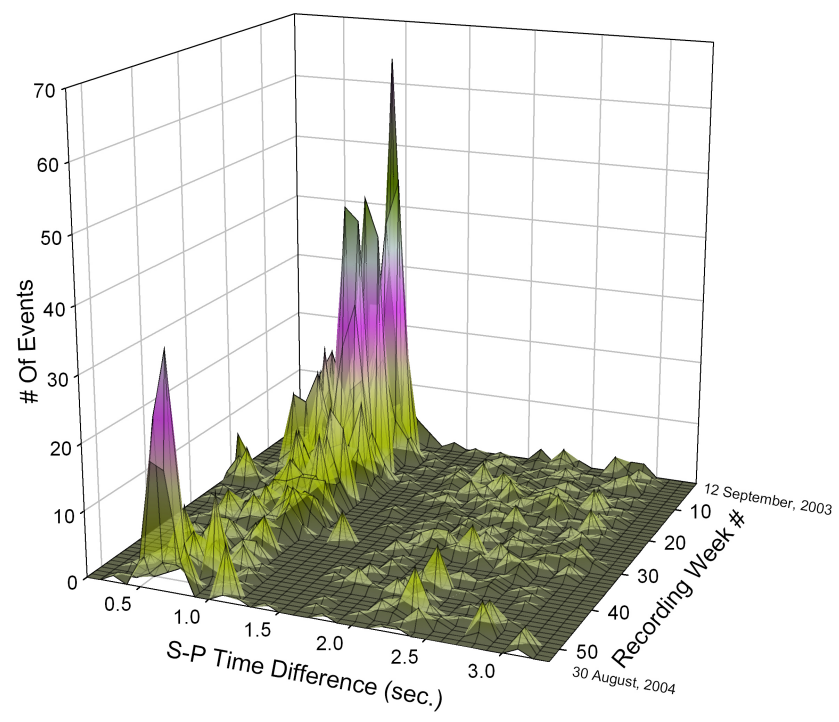

Fig. 6. 3-D plot showing the number of events of a particular S$\mathrm{P}$ time difference recorded at NSH during 2003-2004. Note the consistent lack of events in the 1.3-1.8 second interval.

Center (AEIC), moved the epicenter approximately $10 \mathrm{~km}$ northeast, placing it on the west edge of the northern, and most active, portion of our defined trend (Fig. 7). The relocation was computed using regionally calibrated Pg and $\mathrm{Sg}$ velocities using the model and methodology described in Mackey (1999) and Mackey et al. (2003).

Relocations of all other ISC reported epicenters following the 9 December 2002, event, except the 31 January 2003, event, also cluster on or near the proposed Loloveem fault. Overall, these locations are a significant improvement over the ISC determined epicenters, with two events moving about $100 \mathrm{~km}$ (Fig. 7).

One event recorded during the Neshkan station deployments ( $3 \mathrm{~h} 49 \mathrm{~min}, 22$ September) was clearly recorded by three Alaska stations as well. Using Alaska data, the event was relocated a few kilometers to the northeast, but within the aftershock zone (Fig. 7). The relocated depth converged to $13.2 \mathrm{~km}$. In all locations and relocations, there is a tradeoff between depth and the distance from Neshkan.

Although there are no historical records of felt earthquakes in the Neshkan area prior to the settlement of the town in the mid-1950s, place names in the Chukchi language suggest that the area could have been known for its seismic instability. There is a word in the Chukchi language for "earthquake" which sounds like "nutevivrelet" or "nuteskivilet" and, as in both English and Russian, is composed of two words "nuteskyn" - Earth, and "vivrelet" - shaking.

The toponymy of rivers, lagoons, and, especially, mountains and hills found in the region of Neshkan, suggest possible links with earthquakes or their traces. For example, mountains have such names as "Elyulivoigyn" - moving or shivering mountain, "Eletkun" - dancing mountain, 


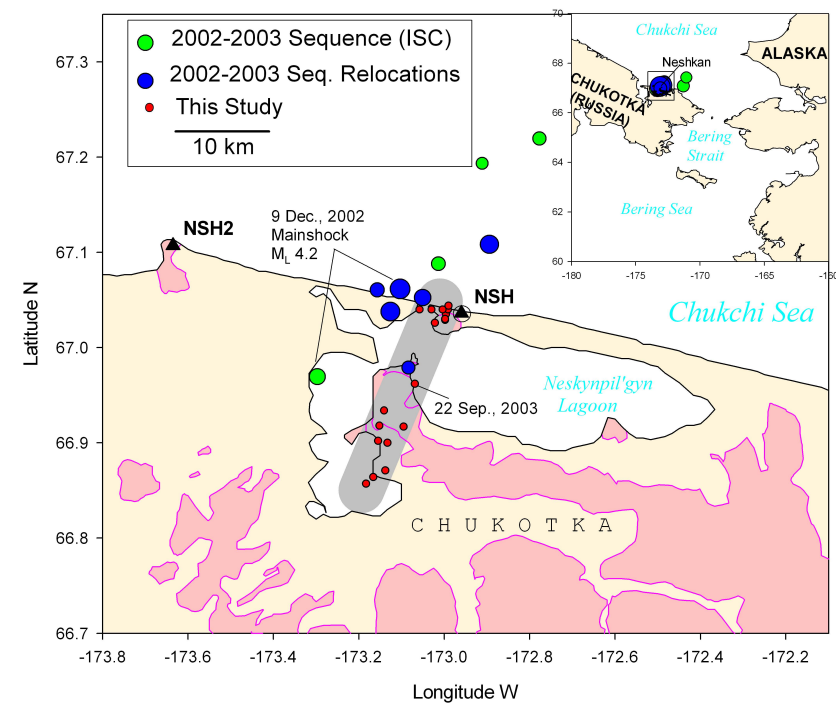

Fig. 7. Comparison of ISC and relocated epicenters of teleseismically recorded events from 2002-2003 and the trend defined in this study. Note the close association of the mainshock relocation to the new trend. Pre-Quaternary outcrop shown in pink.

and "Ivuichin" - moving mountain. Other mountains and hills, have names that reflect the opposite - stability, e.g., Mt. "Ymilinei" - full (whole) mountain, and Mt. "Irvymylinei" - sharp (high) mountain or cowl. Lakes have names like "Einekuem" - buzzing, and "Tyl'pygyt" - abrupt, truncated, or half. "Einekvun" lagoon means vibrating height, and the word "eletkonvyn" - vibrating. In the Chukchi language there is also the word "nuteskivilet" - rotten Earth, which is a homonym to the word for earthquake. According to the explanation of the translator, such "rotten Earth" represents a section of cracked surface, the movement on which is dangerous both for people as well as for reindeer due to the penetrating cracks; this description seems similar to the broken, eroded ground west of Neshkan.

\section{Tectonic interpretation of the swarm}

The exact local cause or association of events occurring on the Loloveem fault (Figs. 4, 7, and 8) is not completely clear. In the general sense, the fault represents an active structure associated with the extensional regime in western Alaska and Chukotka, on the northern boundary of the Bering plate (Mackey et al., 1997; Fujita et al., 2002). The events clearly define a linear trend, but as noted, there is a gap in the distribution. The currently active region appears to have events concentrated into northern and southern clusters, separated by about $8-10 \mathrm{~km}$ (Fig. 7). We do not know if this has been the case since the sequence began on 9 December 2002. It is possible that the events are migrating outward from the rupture of the $M_{L} 4.2$ mainshock (although the event is likely too small for this to be the rupture length) or that of the $M_{w} 6.1$

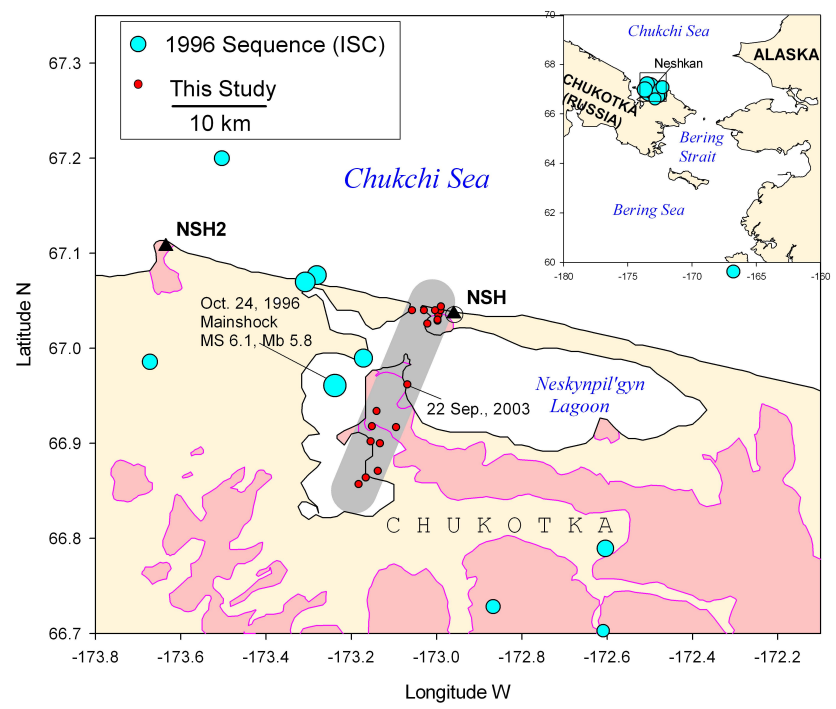

Fig. 8. Comparison of teleseismic locations of the 24 October 1996 earthquake and associated aftershocks to the currently active portion of the Loloveem fault. The 1996 sequence may fall on the same fault segment, with location differences being due to epicenter calculation errors. Pre-Quaternary outcrop shown in pink.

24 October 1996 earthquake (for which a 8-10 km rupture is more consistent; Fig. 8); the events recorded in our study being "triggered" aftershocks at the ends of the rupture zone where stress increases have been calculated for larger events (e.g., Stein et al., 1992). Another speculation is that the 3 November 2002, Denali Fault earthquake in Alaska caused a stress change in the region and "reactivated" the fault segment.

It should be noted that the strike of the Loloveem fault is parallel to the Chegitun fault of Natal'in (1999) and trends of earthquakes in the Kolyuchin-Mechigmen graben region (as relocated by Fujita et al., 2002) and the Bering Strait (Figs. 2 and 3 ).

In terms of the specific nature of faulting, examination of moment tensor and focal mechanism data indicates that these events are occurring in a transtensional setting.

The best mechanism in the Neshkan area is the moment tensor determined for the $M_{w} 6.124$ October 1996 event (Fig. 2). The solution indicates right-lateral transtension on an east-northeast striking plane $\left(\phi_{s}=249^{\circ}, \theta=63^{\circ}, \lambda=-134^{\circ}\right.$; Dziewonski et al., 1998). A second, smaller $\left(M_{w} 5.1\right)$, event occurred in the same area on 24 March 1997 with a similar mechanism of $\left(\phi_{s}=230^{\circ}, \theta=53^{\circ}, \lambda=-160^{\circ}\right.$; Harvard CMT; Fig. 2). In both cases, the azimuth of extension is nearly north-south $\left(9^{\circ}\right.$ and $183^{\circ}$, respectively).

The 5 October 1971 event $\left(m_{b} 5.2, M_{S} 5.0\right)$ is the only predigital era event for which sufficient data are available for a mechanism determination. Biswas et al. (1986) and Fujita and Koz'min (1994) proposed a northwest-southeast extensional normal faulting mechanism based on P-wave first 
motions with a limited azimuthal distribution, however, the first motions from the Alaskan stations which constrained these solutions are emergent and likely erroneous. Body wave modeling and teleseismic first motions indicate instead that the 1971 event is also transtensional $\left(\phi_{s}=267^{\circ}\right.$, $\theta=55^{\circ}, \lambda=-145^{\circ}$, azimuth of extension axis $213^{\circ}$; Fujita et al., 2002). This solution is similar to the moment tensor for the 1996 event, but rotated clockwise about $20^{\circ}$.

The few first motions available for the magnitude 5.5 event of 4 March 1962, and the character of the waveforms suggest that the 1962 event had a mechanism similar to the 1971 event (Fujita and Koz'min, 1994).

Thus, the limited data available suggest that all of the mechanisms are similar and probably transtensional with one of the nodal planes sub-parallel to the coastline (strike 128$155^{\circ}$ ) and the trend of older tectonic features (e.g., Kotzebue arch; Eittreim et al., 1979) while the other, east-northeast $\left(50-97^{\circ}\right)$ striking plane is sub-parallel to the strike of the seismicity. This is consistent with the interpretation by both Toro et al. (2003) and Fujita et al. (2002) that the northeast striking faults (Fig. 3), including the Loloveem, are rightlateral strike-slip (Fig. 3). Centroid moment tensor mechanisms for several events in the Bering Strait also have similar transtensional mechanisms with a northeast-striking nodal plane parallel to the trend of the seismicity (Fig. 2).

The Loloveem fault may simply define the eastern edge of the presently subsiding Kolyuchin basin and whose exact relationship with the extension in easternmost Chukotka is, as yet, unknown. Alternatively, the Kolyuchin basin and the Kolyuchin-Mechigmen graben may represent a series of pullapart basins offset by transfer faults of northeast-southwest strike; this interpretation is unlikely since it would require the transfer faults to be left-lateral and all focal mechanisms and geologic data indicate right-lateral motions. In addition, the general location of subsidence does not appear to follow any specific pattern.

However, the fact that all distinct seismicity trends are oriented northeast-southwest throughout eastern Chukotka and the Bering Strait, and focal mechanisms indicate right-lateral transtension, suggests the possibility that the entire zone of active seismicity located at the northern edge of the Bering plate contains many through-going strike-slip faults with the specific locations of basin or rift formation controlled by the local geology. On a large scale, a similar distribution of basins (Kirschner, 1994) may exist between the large strikeslip faults of western Alaska.

Although there are many lines of evidence indicating that the Neshkan region, as well as eastern Chukotka and the Seward Peninsula as a whole, is within a generally N-S extensional regime, additional study will be necessary to present a detailed tectonic model; the larger earthquakes in the Neshkan, Bering Strait, and Seward Peninsula regions all seem to represent right-lateral transtensional faulting under this $\mathrm{N}-\mathrm{S}$ extension.

\section{Koryak events}

The seismicity of the Neshkan region continues to the southwest into the Koryak highlands where it is presumed to delineate the western edge of the Bering Plate (Mackey et al., 1997; Fujita et al., 2002). Two large clusters of earthquakes have occurred along this trend, the most recent beginning in April 2006.

Until recently, the 1928 sequence of earthquakes in the vicinity of Neshkan were the largest known to have occurred on the North America-Bering plate boundary. This changed on 20 April 2006, with the occurrence of the $M_{w} 7.7$ Olyutorka earthquake in the Koryak Highlands, along the northwestern edge of the boundary (Fig. 9; Chebrov, 2007). This earthquake was a northeast-southwest striking thrust event that ruptured approximately $180-200 \mathrm{~km}$ along strike of the fault, based on the initial aftershock distribution. The event location, thrust mechanism, and fault orientation are all consistent with the North American-Bering boundary and its motion (northwest-southeast compression) as proposed by Mackey et al. (1997). The location and moment tensor of the mainshock is essentially the same as the $M_{w} 6.6$ event in 1991.

On 9 May 2006 a $M_{w} 5.8$ earthquake occurred just off the northwestern corner of the aftershock zone. This event differed in that the moment tensor indicated a primarily strike slip event. This was followed by a similar $M_{w} 6.7$ strike-slip earthquake on 22 May 2006, in the same vicinity. The aftershock zones from these strike slip events fall to the north of the main thrust zone and may indicate strain partitioning along the plate boundary; the regional stress change resulting from the 20 April earthquake activated an adjacent region of strike slip faulting. Alternatively, the strike slip mechanisms may represent a right-lateral transform fault that extends northwestward from the southern end of the ruptured thrust fault, as defined by the aftershock zone. A plot of USGS located aftershocks occurring after the 9 May 2006 event (Fig. 9) indicates that almost all events concentrate in the vicinity of the strike-slip events; large aftershocks associated with the main thrust event are generally absent. The strike-slip aftershocks appear to trend northwest, most consistent with the right-lateral transform fault hypothesis. There are no clear fault traces visible on the available satellite images that could be associated specifically with either the thrust or strike-slip faults.

Relative GPS data for the Bering plate and the adjacent North American plate in Asia also indicate a component of compression across the Koryak Highlands (Cross and Freymueller, 2008).

The distribution of aftershocks and faulting from the large Koryak events of April and May 2006 will be better understood after ongoing fieldwork and data from temporary seismic stations deployed by the Kamchatka and Magadan seismic networks are analyzed. Combined with the seismic swarm at Neshkan, the recent sequence of events in the 


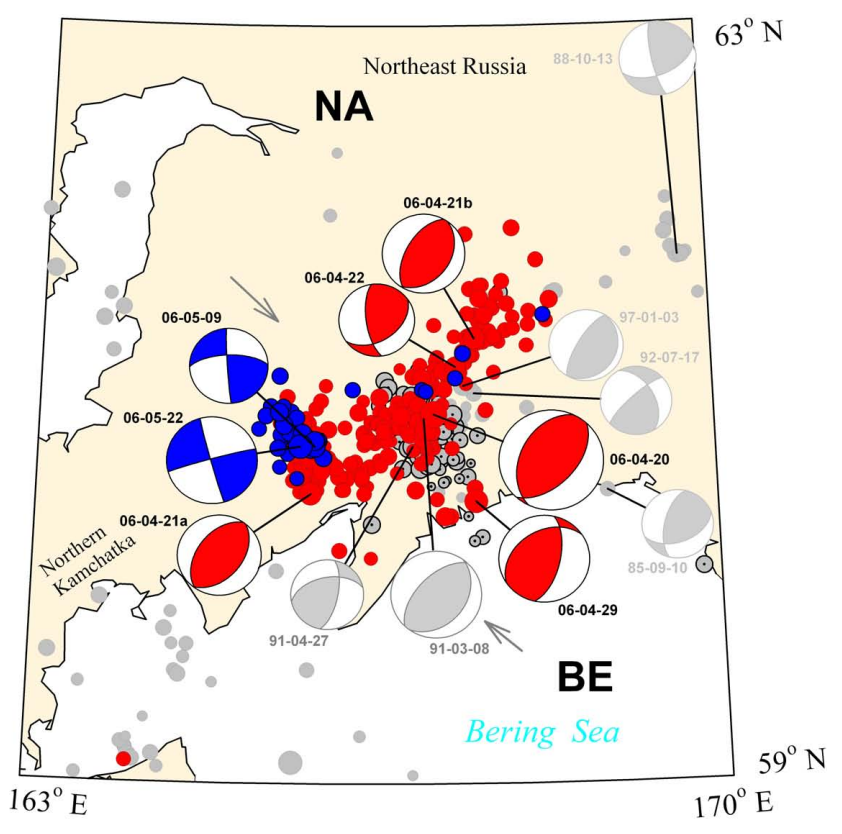

Fig. 9. Seismicity of the Koryak Highlands showing the initial USGS determined epicenters of the 20 April $2006 M_{w} 7.7$ Olyutorka earthquake and its aftershocks (red). Aftershocks occurring after the 9 May 2006 strike-slip event concentrate to the northwest corner of the main aftershock zone, and may represent rupture on a second fault (blue). Aftershocks from the 1991 event are shown as grey circles with a dot, and solid grey circles are all other events located in the region. All symbol sizes are scaled to event size. All focal mechanisms shown are best double couple solutions as listed in the Harvard Moment Tensor catalog; compressional quadrants shaded. NA - North American plate, BE - Bering plate.

Koryak Highlands reiterates that the level of seismic activity along the northern Bering plate boundary is higher than is generally recognized by the seismological community.

\section{Conclusions}

Eastern Chukotka is a tectonically active region. Historically, this is most evident in the vicinity of Neshkan, where several magnitude $>6$ earthquakes have occurred since the early part of the 20th century. The recent activity in the Neshkan region has allowed us the first opportunity in Chukotka to study an aftershock sequence at close range. This study resulted in the identification of the Loloveem fault, which is the first specifically identified active fault in the region associated with a linear trend of earthquakes. This fault is suggested to be a transtensional feature defining the eastern edge of the Kolyuchin basin and/or a transfer (transform) fault within the Chukotka-Seward extensional zone at the northern edge of the Bering plate (Fig. 1); other geologically mapped strikeslip faults have a similar strike. The exact nature of the neotectonic basins in eastern Chukotka is, as yet, poorly known.
It is essential to continue studying both the Neshkan region, as well as seismicity throughout eastern Chukotka, western Alaska, and the Bering Strait, to understand the tectonic processes associated with both the interaction of the Bering and North American plates as well as with the entire North Pacific plate boundary zone region.

Acknowledgements. We would like to thank Maisie Nichols and Hillary Ott for assistance with data entry. Alaska network data was provided by Natasha Ruppert and the Alaska Earthquake Information Center (AEIC). Data processing was made possible through assistance from Hans Hartse and Ilya Prostakeshin. Raisa A. Taranova, village administrator of Neshkan, compiled the listing of felt earthquakes. We thank Brian Hampton for useful discussions and Natasha Ruppert and Vladimir Verzhbitsky for helpful reviews.

This project was funded by US DoE contracts DE-FC0302SF22490 and DE-FC52-2004NA25540. Generous funding from MChS RF, Anadyr office, and the village of Neshkan also provided assistance for this project.

\section{References}

Akinin, V. V. and Apt, Y. E.: Enmelen volcanoes (Chukchi Peninsula): Petrology of Alkaline Lavas and Deep-Seated Inclusions. SVKNII, Magadan, 1994 (in Russian).

Aksenov, A. A., Dunaev, N. N., Ionin, A. S.., Kalinenko, V. V., Medvedev, V. S., Pavlidis, Y. A., and Yurkevich, M. G.: The Arctic shelf of Eurasia in Late Quaternary time. Nauka, Moscow, 1987 (in Russian).

Anikeev, N. P., Vas'kov'skii, A. P., Drabkin, I. E., Popov, G. G., and Titov, V. A.: Tectonics, in: Northeast USSR, Geology of the USSR, 30, pt. 2, edited by: Drabkin, I. E., Nedra, Moscow, 247-423, 1970 (in Russian).

Belyi, V. F.: Okhotsk-Chukotka volcanogenic belt, Cenozoic volcanism, Magmatism, in: Northeast USSR, Geology of the USSR, 30, pt. 2., edited by: Drabkin, I. E., Nedra, Moscow, 225-226, 1970 (in Russian).

Bering Strait Field Party: Koolen metamorphic complex, NE Russia: Implications for the tectonic evolution of the Bering Strait region, Tectonics, 16, 713-729, 1997.

Biswas, N. N., Aki, K., Pulpan, H., and Tytgat, G.: Characteristics of regional stresses in Alaska and neighboring areas, Geophys. Res. Lett., 13, 177-180, 1986.

Chebrov, V. N. (Ed.): Olyutorka Earthquake of 20 (21) April 2006 in the Koryak Highlands - First Results of Investigations, Kamchatka Filial, Geophysical Survey, Russian Academy of Sciences, CD, 2007.

Cheshko, A. L., Dubinina, E. O., Vakin, E. A., Lavrushin, V. Y., and Polyak, B. G.: The first data on hydrogen and oxygen isotopic compositions in the thermal mineral waters of eastern Chukotka, Dokl. Earth Sci., 395, 425-428, 2004.

Cross, R. S. and Freymueller, J. T.: Evidence for and implications of a Bering plate based on geodetic measurements from the Aleutians and western Alaska, J. Geophys. Res., 113, B07405, doi:10.1029/2007JB005136, 2008.

Dumitru, T. A., Miller, E. L., O'Sullivan, P. B., Amato, J. M., Hannula, K. A., Calvert, A. T., and Gans, P. B.: Cretaceous to Recent 
extension in the Bering Strait region, Alaska, Tectonics, 14, 549563, 1995.

Dziewonski, A. M., Ekström, G., and Maternovskaya, N. N.: Centroid-moment tensor solutions for October-December 1996, Phys. Earth Planet. In., 105, 95-108, 1998.

Eittreim, S., Grantz, A., and Whitney, O. T.: Cenozoic sedimentation and tectonics of Hope Basin, southern Chukchi Sea, in: The Relationship of Plate Tectonics to Alaskan Geology and Resources, edited by: Sisson, A., Alaska Geological Society, Anchorage, B-1-B-11, 1979.

Fujita, K. and Koz'min, B. M.: Seismicity of the Amerasian Arctic shelf and its relationship to tectonic features, in: 1992 Proceedings International Conference on Arctic Margins, edited by: Thurston, D. K. and Fujita, K., US Mineral Management Service, OCS Study MMS 94-0040, 307-312, 1994.

Fujita, K., Mackey, K. G., McCaleb, R. C., Gunbina, L. V., Kovalev, V. N., Imaev, V. S., and Smirnov, V. N.: Seismicity of Chukotka, northeastern Russia, Geol. S. Am. S., 360, 259-272, 2002.

Gorodinsky, M. E. (Ed.): Geologic Map of the Northeast USSR. Vsesoyuz Nauchnyi-Issledovatel'sky Geologichesky Institut, Leningrad, scale 1:5000 000, 1982 (dated 1980).

Grantz, A., May, S. D., and Hart, P. E.: Geology of the Arctic continental margin of Alaska, in: The Geology of Alaska, The Geology of North America, G-1, edited by: Plafker, G. and Berg, H. C., Geological Society of America, Boulder, 17-48, 1994.

Grantz, A., Scholl, D. W., Toro, J., and Klemperer, S. L.: Geologic structure of Bering and Chukchi shelves adjacent to BeringChukchi deep transect and tectonostratigraphic terranes of adjacent landmasses, Geol. S. Am. S., 360, scale 1:3000 000, 2002.

Grinenko, O. V., Sergeenko, A. I., and Belolyubsky, I. N.: Paleogene and Neogene of Northeastern Russia, pt 1. Izd-vo YaNTs SO RAN, Yakutsk, 1998.

Hudson, T. and Plafker, G.: Kigluaik and Bendeleben faults, Seward Peninsula, US Geological Survey Circular, 772-B, B47B50, 1978.

Kirschner, C. E.: Interior basins of Alaska, in: The Geology of Alaska, The Geology of North America, G-1, edited by: Plafker, G. and Berg, H. C., Geological Society of America, Boulder, 469-493, 1994.

Lander, A. V., Bukchin, B. G., Kiryushin, A. V., and Droznin, D. V.: The tectonic environment and source parameters of the Khailino, Koryakia earthquake of March 8, 1991: Does a Beringia plate exist?, Computational Seismology and Geodynamics, 3, 80-96, 1996.

Lazareva, A. P.: Earthquakes of the Arctic in 1970 and 1971, in: Earthquakes of the USSR in 1971, edited by: Gorbunova, I. V., Kondorskaya, N. V., and Shebalin, N. V., Nauka, Moscow, 145149, 1975 (in Russian).

Mackey, K. G., Fujita, K., Gunbina, L. V., Kovalev, V. N., Imaev, V. S., Koz'min, B. M., and Imaeva, L. P.: Seismicity of the Bering Strait region: Evidence for a Bering block, Geology, 25, 979982, 1997.

Mackey, K. G.: Seismological Studies in Northeast Russia, Ph.D. Dissertation, Michigan State University, 1999.
Mackey, K. G., Fujita, K., Steck, L. K., and Hartse, H. E.: Seismic regionalization in eastern Russia, in: Proceedings of the $25^{\text {th }}$ Seismic Research review - Nuclear Explosion Monitoring: Building the Knowledge Base, National Nuclear Security Administration, US Department of Energy, LA-UR-03-6029, 7382, 2003.

Moll-Stalcup, E. J.: Latest Cretaceous and Cenozoic magmatism in mainland Alaska, in: The Geology of Alaska, The Geology of North America, G-1, edited by: Plafker, G. and Berg, H. C., Geological Society of America, Boulder, 589-620, 1994.

Natal'in, B. A.: Late Cretaceous - Tertiary deformations in the Chukotka Peninsula: Implications for the origin of the Hope Basin and the Herald thrust belt (Chukchi Sea), Geotectonics, 33, 489-504, 1999.

Natal'in, B. A., Amato, J. M., Toro, J., and Wright, J. E.: Paleozoic rocks of northern Chukotka Peninsula, Russian Far East: Implications for the tectonics of the Arctic region, Tectonics, 18, 977-1003, 1999.

Pol'kin, Y. I.: Chukchi Sea, in: Geologic Structure of the USSR and Regularities in the Distribution of Mineral Resources, 9, Seas of the Soviet Arctic, edited by: Gramberg, I. S. and Pogrebitsky, Y. E., Nedra, Leningrad, 67-79, 1984 (in Russian).

Polyak, B. G., Lavrushin, V. Y., Cheshko, A. L., Vakin, E. A., and Dubinina, E. O.: Geothermal resources of the Chukchi Peninsula, Proc. World Geothermal Congress, Antalya, Turkey, paper 19-25, 2005.

Shipilov, E. V.: On the graben-rift system of the Chukchi Sea, Izv. AN SSSR Geol., 1989(10), 96-107, 1989 (in Russian).

Shipilov, E. V., Senin, B. V., and Yunov, A. Y.: Sedimentary cover and basement of the Chukchi Sea from seismic data, Geotectonics, 23, 456-463, 1989.

Stein, R. S., King, G. C. P., and Lin, J.: Change in failure stress on the southern San Andreas fault system caused by the 1992 Magnitude=7.4 Landers earthquake, Science, 258, 1328-1332, 1992.

Till, A. B., and Dumoulin, J. A.: Geology of Seward Peninsula and Saint Lawrence Island, in: The Geology of Alaska, The Geology of North America, G-1, edited by: Plafker, G. and Berg, H. C., Geological Society of America, Boulder, 141-152, 1994.

Tolson, R. B.: Structure and stratigraphy of the Hope Basin, southern Chukchi Sea, Alaska, in: Geology and Resource Potential of the Continental Margin of Western North America and Adjacent Ocean Basins - Beaufort Sea to Baja California, edited by: Scholl, D. W., Grantz, A., and Vedder, J. G., Earth Science Series 6, Circum-Pacific Council for Energy and Mineral Resources, Houston, 59-71, 1987.

Toro, J., Amato, J. M., and Natal'in, B.: Cretaceous deformation, Chegitun River area, Chukotka Peninsula, Russia: Implications for the tectonic evolution of the Bering Strait region, Tectonics, 22(3), 1021, doi:10.1029/2001TC001333, 2003.

Turner, D. L. and Forbes, R. B. (Eds.): A Geological and Geophysical Study of the Geothermal Energy Potential of Pilgrim Springs, Alaska, Geophysical Institute, University of Alaska, UAG R271,1980 